\title{
A Scenario-Based Approach for Assessing the Hydrological Impacts of Land Use and Climate Change in the Marboreh Watershed, Iran
}

\author{
Ali Torabi Haghighi ${ }^{1}\left(\mathbb{D} \cdot\right.$ Hamid Darabi $^{1,2} \cdot$ Kaka Shahedi $^{2} \cdot$ Karim Solaimani $^{2} \cdot$ Bjørn Kløve $^{1}$
}

Received: 4 June 2017 / Accepted: 3 April 2019 / Published online: 29 April 2019

(C) The Author(s) 2019

\begin{abstract}
In separate analyses of the impacts of land use change and climate change, a scenario-based approach using remote sensing and hydro-climatological data was developed to assess changes in hydrological indices. The data comprised three Landsat TM images $(1988,1998,2008)$ and meteorological and hydrological data (1983-2012) for the Aligudarz and Doroud stations in the Marboreh watershed, Iran. The QUAC module and supervised classification maximum likelihood (ML) algorithm in ENVI 5.1 were used for remote sensing, the SWAT model for hydrological modelling and the Mann-Kendall and $t$ test methods for statistical analysis. To create scenarios, the study period was divided into three decades (1983-1992, 1993-2002, 2003-2012) with clearly different land use/land cover (LULC). After hydrological modelling, 10 hydrological indices related to high and low flow indices (HDI and LDI) were analysed for seven scenarios developed by combining pre-defined climate periods and LULC maps. The major changes in land use were degradation of natural rangeland $(-18.49 \%)$ and increasing raid-fed farm area $(+$ $16.70 \%)$ and residential area $(+0.80 \%)$. The Mann-Kendall test results showed a statistically significant $(p<0.05)$ decreasing trend in rainfall and flow during 1983-2012. In the scenarios evaluated, hydrological index trends were more sensitive to climate change than to LULC changes in the study area. Low flow indices were more affected than high flow indices in both land use and climate change scenarios. The results show little impact of land use change and indicate that climate change is the main driver of hydrological variations in the catchment. This is useful information in outlining future strategies for sustainable water resources management and policy decision-making in the Marboreh watershed.
\end{abstract}

Keywords Land use/land cover $\cdot$ Climate variability $\cdot$ Scenario $\cdot$ Hydrological indices

\section{Introduction}

An increasing amount of water is required to meet the growing human demand for food world-wide, causing conflicts between water supply and demand in water-scarce regions [77]. Climate change and changes in land use/land cover (LULC) are the main factors influencing water availability, as they can alter hydrological processes (e.g. flood frequency, severity and annual mean discharge). Thus, assessing the impacts of LULC change (LULCC) and climate change on hydrological conditions has become one of the greatest

Ali Torabi Haghighi

ali.torabihaghighi@oulu.fi

1 Water, Energy and Environmental Engineering Research Unit, University of Oulu, P.O. Box 4300, FIN-90014 Oulu, Finland

2 Sari Agriculture Science and Natural Resources University, P.O. Box 737, Sari, Iran challenges in hydrological research [29, 77]. Moreover, LULCC and climate change/variability (i.e. anthropogenic and natural) are both likely to affect the hydrological cycle and consequently water resources in many river basins (e.g. [26, 76]; Pervez and Henebry 2015; [18, 36, 77]). It is important to assess such changes and a number of studies have already demonstrated that human activities such as LULCC can lead to changes in the hydrological response of watersheds (e.g. $[71,77,78]$ ) and that climate change/variability can affect precipitation, runoff and flood frequency (e.g. [5, 8, 9, 24, $28,42,56,58,61,63,73])$.

Changes in LULC affect partitioning of precipitation through vegetation and soil into the main water balance components of interception, infiltration, evapotranspiration, surface runoff and groundwater recharge $[66,74]$. In arid and semi-arid regions, the climate and LULC are closely linked and these links must be understood when seeking to assess climate change impacts on hydrology, water resources and associated ecosystem services [74]. Moreover, climate change/variability is expected to affect precipitation and 
evapotranspiration patterns, a process which is not well understood, but will affect regional and local water availability, river hydrology and the seasonal availability of water supply $[3,8,27,65]$. Many studies have examined the impacts of LULC change and climate change on watershed hydrology (e.g. $[2,6,23,25,32,34,37,39,54,64,68,72,77,79]$ ). Others have assessed the combined effect of LULC change and climate change on the quantity and quality of water resources (e.g. [12, 26, 55, 60, 69, 75]). Most of those studies have analysed the effects of LULCC and climate change using hydrological models ranging from very simple water balance models to complex models such as the Annualized Agricultural Non-Point Source model (AnnAGNPS) and Soil Water Assessment Tool (SWAT), which are able to simulate a variety of water resource components $[12,79]$.

Research to date has improved understanding of the impacts of climate change and LULCC on hydrology and water resources and water availability, especially at large scales. However, determining how climate change and LULCC might affect hydrological conditions regionally and locally is a challenge, as the extent of climate change and LULCC at regional level is uncertain, especially in developing countries where there is a lack of data. For efficient hydrology and water resource management, there is a clear need to understand flow variability over time and extreme endpoints. Therefore, the aim of this study was to develop and refine a framework for analysis of extreme hydrological responses to LULCC and climate change in terms of daily flow regime. The novel contribution of this framework is generation of data on potential hydrological changes based on observed hydrological, land use and climate data. In addition, the focus is mainly on extreme data, through indices related to low flow (LDI) and high flow (HDI), whereas in most previous studies on hydrological changes, the major emphasis has been on mean values (e.g. $[26,46,54,81])$. Identifying any hydrological changes that occur, especially in low-flow conditions, would help in devising a solution to protect ecological processes through environmental flow allocation [80]. It would also assist in the development of adaptation and mitigation strategies regarding climate change and land use change for critical natural habitats. In this study, the framework was tested by applying it to the case of the Marboreh River (located in the semi-arid region of Iran), which is a very important habitat for many aquatic species. The analysis was based on data from three Landsat TM images $(1988,1998,2008)$ and on meteorological and hydrological data (1983-2012) recorded at the Aligudarz and Doroud stations in the Marboreh watershed. The SWAT model and statistical analysis were also used in analysis of scenarios, to distinguish the impacts of LULCC from those of climate change/variability. The aim was to achieve a better understanding of the impacts of LULCC and climate change on water resources, information which is needed by planners and decision makers.

\section{Methods and Materials}

\subsection{Case Study and Data}

The Marboreh watershed $\left(2710 \mathrm{~km}^{2}\right)$ extends between $49^{\circ} 03^{\prime}$ $51^{\prime \prime}$ to $49^{\circ} 58^{\prime} 22^{\prime \prime}$ East and $33^{\circ} 11^{\prime} 05^{\prime \prime}$ to $33^{\circ} 49^{\prime} 45^{\prime \prime}$ North (Fig. 1). The climate in the region is semi-arid (aridity index 0.326), with 397-mm annual precipitation (mean 1983-2012) and $1215-\mathrm{mm}$ potential evapotranspiration based on the Thornthwaite equation [51]. Mean annual runoff $(R)$ for 1983-2012 was $256 \mathrm{~mm} /$ year, resulting in a long-term runoff to precipitation ratio (R/P) of 0.64. Climate data (1983-2012), including daily rainfall, maximum and minimum temperature, wind speed and relative humidity observations for the Aligudarz station, were obtained from the Iranian Meteorological Organisation (IRIMO). Data on observed daily discharge at the Doroud station (located at the outlet of the Marboreh watershed) were obtained from Lorestan Regional Water Authority. The soil in the watershed consists of four types [15]. The digital elevation model (DEM, $30 \mathrm{~m}$ ) for the area was downloaded from the USGS Server. Land use data in 1988, 1998 and 2008 were prepared from Landsat images.

\subsection{Land Use/Land Cover Maps}

Landsat multispectral images (from the USGS dataset) were used for preparing the land use map. The Landsat images consisted of Landsat 5 Thematic Mapper images (TM Path/Row: 165/037) acquired on 9 August 1988, 10 June 1998 and 21 June 2008. The images comprised seven spectral bands (from $b 1$ to $b 5$ and $b 7$ ) with a spatial resolution of $30 \mathrm{~m}$ (120 $\mathrm{m}$ for thermal band 6). Atmospheric correction is a necessary step in accurately extracting quantitative information from Landsat $[30,38]$. In image pre-processing, atmospheric correction of Landsat 5 images was carried out using QUick Atmospheric Correction (QUAC) in ENVI 5.1. The supervised classification and maximum likelihood algorithm in ENVI $5.1[10,48]$ was then employed to process and classify the images. There are seven land use types in the Marboreh watershed: dry farming, irrigation farming, rangeland, bare land, orchard, outcrop and residential area. Accuracy assessment is an essential and most crucial part of image processing $[7,11]$. The overall classification accuracy and kappa coefficient were used to determine the accuracy of classification, using the ENVI v.5.1 software [48]. Based on the Landsat images, land use maps were generated for 1988 , 1998 and 2008, as illustrated in Fig. 2. Changes in the different land use types (dry farming, irrigation farming, rangeland, bare land, orchard, outcrop and residential area) are listed in Table 1.

Rangeland, the most commonly distributed land use type in the Marboreh watershed, showed a decreasing trend of 9.93, 18.40 and $6.34 \%$ during $1988-1998,1988-2008$ and 1998 


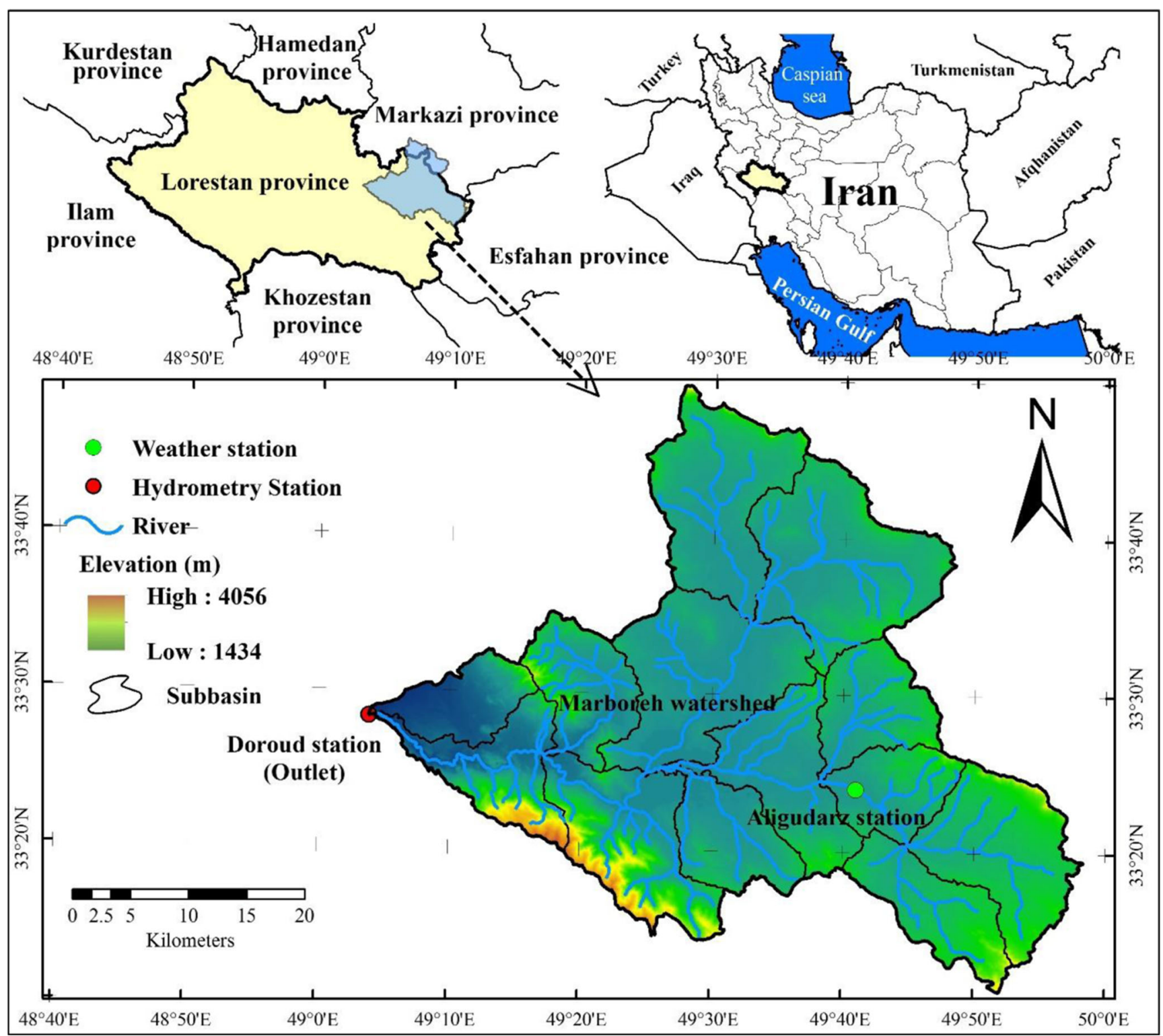

Fig. 1 Location of the Marboreh catchment and study area in Iran

2008, respectively (Table 1). Rainfed farmland area, mainly in the plains and lowlands of the study area, increased by $8.32 \%$, $14.66 \%$ and $8.47 \%$ during $1988-1998,1988-2008$ and $1998-$ 2008 , respectively. Orchards, a common land cover on river edges, increased by $0.19,0.53$ and $0.34 \%$ during $1988-1998$, 1988-2008 and 1998-2008, respectively. Residential area increased by $0.34,0.80$ and $0.46 \%$ during $1988-1998,1988-$ 2008 and 1998-2008, respectively. Irrigated and bare land area also increased from 1988 to 2008 in the Marboreh watershed (Table 1). An accuracy assessment of land use classification, obtained by computing the confusion matrix in ENVI software, showed an overall accuracy value of $79.36 \%$ for 1988, $80.38 \%$ for 1998 and $81.40 \%$ for 2008 . The kappa coefficient for 1988, 1998 and 2008 was $0.71,0.75$ and 0.78 , respectively.

\subsection{Scenario Settings}

To evaluate the response of daily flow indices to land use changes and climate change, the daily flows were simulated by changing the land use under specific climate conditions, and vice versa. Different scenarios were developed by combining the different land use maps and climate periods. For this purpose, the available meteorological data from 1983 to 2012 were divided into three decades (climate periods 19831992 (hereafter called C1), 1993-2002 (C2) and 2003-2012 (C3)). The land use maps were extracted based on the Landsat TM5 images for the middle year of each period (1988 (hereafter LU1), 1998 (LU2) and 2008 (LU3)). Nine sets of land use and climate conditions were obtained by combining three climate periods (C1-3) and three land use maps (LU1-3), to 

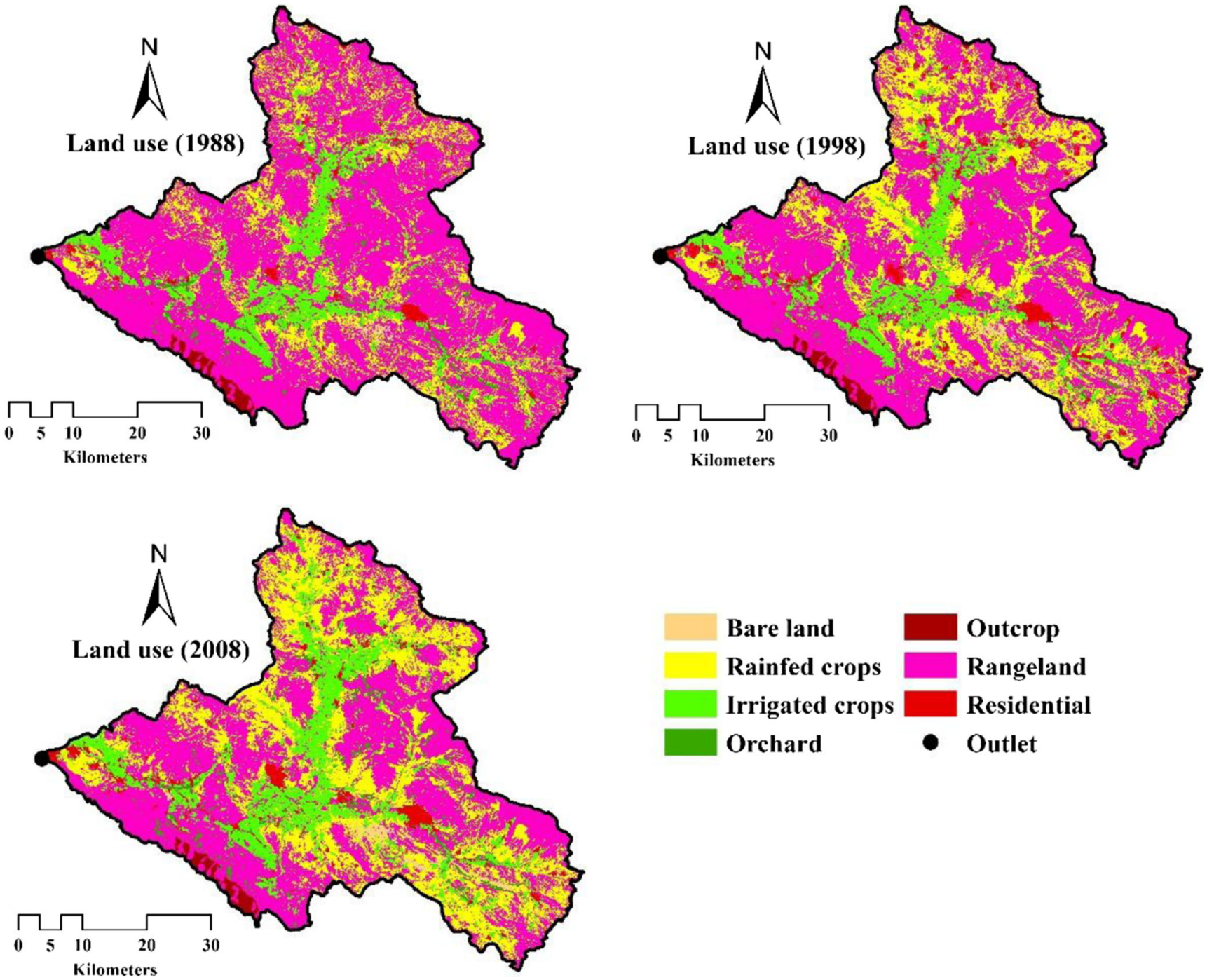

Fig. 2 Land use maps of the Marboreh watershed for 1998, 1998 and 2008, based on Landsat TM images

give C1_LU1, C2_LU2 and C3_LU3 as historical conditions, and C1_LU2, C1_LU3, C2_LU1, C2_LU3, C3_LU1 and C3_LU2 as virtual conditions. The values of hydro-climate parameters in the Marboreh watershed for three decades (1983-1992, 1993-2002 and 2003-2012) are presented in
Table 2. As can be seen from the table, the mean values of discharge and precipitation decreased from 1983-1992 to 2003-2012. In addition, the 10th percentile value for discharge decreased from 1983-1992 to 2003-2012 and that for precipitation increased. The 90 th percentile of discharge
Table 1 Areal distribution of land use/land cover categories in the Marboreh watershed

\begin{tabular}{|c|c|c|c|c|c|c|}
\hline \multirow[t]{2}{*}{ Land use } & \multicolumn{2}{|c|}{ Land use (TM/1988) } & \multicolumn{2}{|c|}{ Land use (TM/1998) } & \multicolumn{2}{|c|}{ Land use (TM/2008) } \\
\hline & Area $\left(\mathrm{km}^{2}\right)$ & $\%$ & Area $\left(\mathrm{km}^{2}\right)$ & $\%$ & Area $\left(\mathrm{km}^{2}\right)$ & $\%$ \\
\hline Bare land & 3.11 & 0.11 & 10.32 & 0.38 & 12.75 & 0.47 \\
\hline Rainfed crops & 556.10 & 20.52 & 781.55 & 28.84 & 953.48 & 35.18 \\
\hline Irrigated crops & 164.34 & 6.06 & 186.23 & 6.87 & 219.66 & 8.11 \\
\hline Orchard & 22.46 & 0.83 & 27.57 & 1.02 & 36.97 & 1.36 \\
\hline Outcrop & 28.40 & 1.05 & 28.40 & 1.05 & 28.40 & 1.05 \\
\hline Rangeland & 1895.27 & 69.94 & 1626.20 & 60.01 & 1396.84 & 51.54 \\
\hline Residential & 40.30 & 1.49 & 49.72 & 1.83 & 61.98 & 2.29 \\
\hline Total & 2710 & 100 & 2710 & 100 & 2710 & 100 \\
\hline
\end{tabular}


Table 2 Statistical parameters on precipitation and discharge in the Marboreh watershed in three decadal climate periods, 1983 1992, 1993-2002 and 2003-2012

\begin{tabular}{|c|c|c|c|c|c|c|}
\hline & \multicolumn{2}{|l|}{ 1983-1992 } & \multicolumn{2}{|l|}{ 1993-2002 } & \multicolumn{2}{|l|}{ 2003-2012 } \\
\hline & Precipitation & Discharge & Precipitation & Discharge & Precipitation & Discharge \\
\hline Mean & 411.286 & 9.660 & 404.330 & 9.066 & 375.400 & 5.424 \\
\hline SD & 109.401 & 4.828 & 121.700 & 6.778 & 82.599 & 2.061 \\
\hline Skewness & -0.089 & 0.649 & -0.356 & 1.221 & -0.732 & -0.105 \\
\hline Kurtosis & -0.780 & -0.431 & 0.392 & 0.191 & -0.028 & -1.621 \\
\hline 10th percentile & 292.885 & 5.166 & 306.255 & 4.171 & 311.285 & 2.920 \\
\hline 25 th percentile & 339.653 & 6.437 & 364.025 & 4.223 & 326.500 & 3.503 \\
\hline Median & 413.950 & 8.430 & 415.500 & 5.947 & 388.400 & 5.525 \\
\hline 75th percentile & 480.975 & 12.275 & 449.900 & 11.812 & 442.050 & 7.119 \\
\hline 90th percentile & 544.880 & 15.958 & 563.010 & 19.179 & 455.420 & 7.723 \\
\hline
\end{tabular}

also decreased from 1983-1992 to 2003-2012, as did median discharge.

By combining different components, seven time series scenarios were created (Table 3). Scenario 1 (SR1) was a time series generated based on the observed climate and land use. Scenarios SR2 to SR4 considered constant land use during three decades combined with the observed climate, e.g. in SR2 the land use for three decades was LU1 (land use during 1988, assuming no land use change) in combination with C1 for 1983-1992, C2 for 1993-2002 and C3 for 2003-2012 (Table 3). The assumption for scenarios SR5-SR7 was to consider the observed climate for different decades and land uses (Table 3).

Components of C1_LU1, C2_LU2 and C3_LU3 as observed conditions. Components of C1_LU2, C1_LU3, C2_LU1, C2_LU3, C3_LU1 and C3_LU2 as virtual conditions.

\subsection{Hydrological Modelling}

The SWAT model has been widely used for different sizes of watersheds and has been applied to a range of hydrological and/or environmental problems, including assessments of the effects of land use changes and climate change on hydrological conditions (e.g. [13, 49, 54, 46, 14, 77, 79, 44]). SWAT is a conceptual, time-continuous and semi-distributed hydrological and watershed-scale model [59] that was initially developed by the United States Department of Agriculture (USDA) Research Service and Texas A\&M University to predict changes in landscape management practices on water, sediment and chemical yield $[4,41,54]$. It operates on daily time steps but can aggregate the results to monthly or annual output [13]. In this study, Arc SWAT 2012 was set up for the periods 1983-1992, 1993-2002 and 2003-2012 and each period was divided into three parts: warm-up, calibration (1984-1989, 1994-1999 and 2004-2009) and validation (1990-1992, 2000-2002 and 2010-2012). For each decade, one hydrological year (1983-1984, 1993-1994 and 2003-2004) was used to warm up the SWAT model, in order to reduce the effects of the initial conditions. The DEM was used to delimit the drainage area of the watershed, considering the Doroud gauge as an outlet. Based on the DEM, surface slope was classified into five ranges $(<5 \%, 5-15 \%, 15-30 \%, 30-40 \%$ and $>40 \%)$, as one of the requirements for the SWAT model. The different types of land use were parameterised based on the SWAT land use classes chosen. Spatial parameterisation of the SWAT model was performed by dividing the watershed into a series of six hydrological response units (HRU) based on unique soil, land use and slope characteristics.

SWAT calibration was performed automatically using the SWAT Calibration Uncertainty Procedure (SWAT-CUP). SWAT parameters were calibrated using observed stream flow at the Doroud station for three 6-year periods and then validated using the observed stream flow for 3-year periods. In SWAT-CUP, the Sequential Uncertainty Fitting (SUFI-2) program algorithm was used for calibration parameters. Two factors were used to quantify the uncertainty performance: Pfactor, which is the percentage of measured data bracketed by the 95PPU band, and R-factor, the average width of the band divided by the standard deviation of the corresponding measured variable $[1,79]$. Nash-Sutcliffe efficiency (NS) was used to assess the accuracy of the goodness of fit between simulation and observation [40]. It was calculated as

$\mathrm{NS}=1-\frac{\sum_{t=1}^{T}\left(Q_{\mathrm{sim}}^{t}-Q_{\mathrm{obs}}^{t}\right)^{2}}{\sum_{t=1}^{T}\left(Q_{\mathrm{obs}}^{t}-\bar{Q}_{\mathrm{obs}}\right)^{2}}$

where $Q_{\text {obs }}$ is the mean of observed discharge, $Q_{\text {sim }}$ is modelled discharge and $Q_{\mathrm{obs}}{ }^{t}$ is observed discharge at time $t$. The range of NS lies between $-\infty$ and 1.0 (perfect fit).

\subsection{Hydrological Indices}

To assess hydrological changes in different scenarios, 10 different indices (Table 4) were used [33, 35, 43, 57, 62]. These 
were classified into two groups, based on their dependency on high or low hydrological conditions, as high dependency indices (HDI) and low dependency indices (LDI). For example, low-flow pulse count was classified as LDI, because the number of low pulses indicated how many times daily flows fell below the lower threshold during the whole period.

The thresholds for low and high flows were taken as the 25th and 75th percentiles [57] of observed daily flow (19832012, belong to SR1). These thresholds were also used in all other scenarios (SR2-SR7) to enable uniform comparison. For example, the low-flow pulse count index (LFPC) in SR1 was calculated based on the number of events in which the magnitude of daily flow dropped below a lower threshold (for Marboreh watershed below the 25 th percentile of all daily flow, $2.42 \mathrm{~m}^{3} \mathrm{~s}^{-1}$ ).

\subsection{Statistical Analyses}

The Mann-Kendall test and Sen's slope estimator (two statistical nonparametric methods) are widely used for hydroclimatological purposes (e.g. [17, 19, 21, 31, 47, 50, 53]). They were applied here to observed hydro-climatological data (1983-2012) and used to determine the trends in the hydrological indices in the seven time series scenarios (SR1-SR7). SR1 represented historical data under both land use change and climate variability, SR2, SR3 and SR4 represented scenarios under land use change and SR5, SR6 and SR7 represented scenarios under climate change. The KolmogorovSmirnov (K-S) test $[20,45]$ showed that the time series of selected hydrological indices were normally distributed $(p>0.05)$. Therefore, the $t$ test $[20,70]$ was used to evaluate differences between the observed scenario (SR1) and other scenarios (SR2-SR7). All statistical analyses were carried out using SPSS 23.v software.

In the land use scenarios, land use map was considered a constant factor in each scenario and Mann-Kendall and Sen's slope estimator methods were used to assess the impact of climate change on hydrological index trends under each land use scenario. In the climate scenarios, each climate decadal period was considered a constant factor and the Mann-Kendall and Sen's slope estimator methods were used to determine the impact of LULCC on hydrological index trends under each climate scenario. The $t$ test method was used to compare mean values of hydrological indices, in order to assess the impact of LULCC in each land use scenario and also to compare the mean values of hydrological indices, in order to assess the impact of climate variability in each climate scenario. The impact of LULCC and of climate change on hydrological indices was assessed from two aspects: (1) the hydrological indices trend for each scenario separately and (2) by comparing mean values of hydrological indices for each scenario with the historical scenario. 
Table 4 High and low dependency hydrological indices (HDI, LDI) used to assess river regime changes in the Marboreh watershed

\begin{tabular}{|c|c|c|c|c|}
\hline Acronym & HDI & LDI & Description & Units \\
\hline MLF & $\checkmark$ & & Minimum low flow during wettest ${ }^{1}$ month & $\mathrm{mm} /$ day \\
\hline MHF & & $\checkmark$ & Maximum high flow during driest ${ }^{1}$ month & $\mathrm{mm} /$ day \\
\hline LPC & & $\checkmark$ & Number of low-flow pulse ${ }^{2}$ counts for each year & - \\
\hline HPC & $\checkmark$ & & Number of high-flow pulse ${ }^{2}$ counts for each year & - \\
\hline LPD & & $\checkmark$ & Annual low-flow pulse duration (no. of days). & days \\
\hline HPD & $\checkmark$ & & Annual high-flow pulse duration (no. of days) & days \\
\hline DDC & & $\checkmark$ & $\begin{array}{l}\text { Annual low-flow pulse days per annual normal flow days or dryness } \\
\text { duration coefficient }\end{array}$ & - \\
\hline WDC & $\checkmark$ & & $\begin{array}{l}\text { Annual high-flow pulse days per annual normal flow days or wetness } \\
\text { duration coefficient }\end{array}$ & - \\
\hline MLPD & & $\checkmark$ & Mean low-flow pulse duration per event & - \\
\hline MHPD & $\checkmark$ & & Mean high-flow pulse duration per event & - \\
\hline
\end{tabular}

${ }^{1}$ In the Marboreh watershed, the wettest and driest month flows are April and September, respectively

${ }^{2}$ Low-flow pulse defined as a period when flow drops below the 25 th percentile, and high-flow pulse as a period when flow exceeds the 75th percentile, of daily flow in the entire period [57]

\section{Results}

\subsection{Calibration and Validation of SWAT Model and Uncertainty}

The results showed good agreement between discharge observations and the outcomes of SWAT modelling. According to SWAT model, the P-factor was $0.89,0.92$ and 0.85 for $1984-1989,1994-1999$ and 2004-2009, respectively (calibration periods) and $0.89,0.97$ and 0.82 for 1990-1992, 2000-2002 and 2010-2012, respectively (validation periods). The R-factor was, respectively, 0.25 , 0.27 and 0.22 for the 1984-1989, 1994-1999 and 20042009 calibration periods and $0.13,0.11$ and 0.21 for the 1990-1992, 2000-2002 and 2010-2012 validation periods. The NS factor was, respectively, $0.90,0.87$ and 0.84 for the 1984-1989, 1994-1999 and 2004-2009 calibration periods and $0.88,0.82$ and 0.64 for the 1990 1992, 2000-2002 and 2010-2012 validation periods. Hence, based on Abbaspour et al. [1], the uncertainty in the calibration and validation periods of the SWAT model was satisfactory (P-factor $>0.7$, R-factor $<1.5$ ) (Table 5 and Fig. 3). Simulated and measured discharge at the Doroud station showed a good match between time series of observed, calibration period and validation period values (Fig. 3).

Based on model sensitivity, the six top-ranked most sensitive parameters (Table 6) were optimised using the SUFI2 algorithm in SWAT-CUP. In SUFI2, uncertainties in model input, model conceptualisation, model parameters and observed data are considered in the parameter ranges as the procedure tries to capture most of the measured data within the $95 \%$ prediction uncertainty. In the present case, curve number condition II (CN2), base flow alpha factor (ALPHA_BF), base flow alpha factor for bank storage (ALPHA_BNK), saturated hydraulic conductivity (SOL_K), moist bulk density (SOL_BD) and available soil water capacity (SOL_AWC) were identified as the most sensitive parameters in the Marboreh watershed according to SUFI2. The initial and optimised values of the calibrated parameters are presented in Table 6.

Table 5 Level of agreement between the calibration and validation periods used for the SWAT model

\begin{tabular}{|c|c|c|c|c|c|c|}
\hline & \multicolumn{2}{|l|}{ 1983-1992 } & \multicolumn{2}{|l|}{ 1993-2002 } & \multicolumn{2}{|l|}{ 2003-2012 } \\
\hline & $\begin{array}{l}\text { Calibration } \\
1984-1989\end{array}$ & $\begin{array}{l}\text { Validation } \\
1990-1992\end{array}$ & $\begin{array}{c}\text { Calibration } \\
1994-1999\end{array}$ & $\begin{array}{l}\text { Validation } \\
2000-2002\end{array}$ & $\begin{array}{l}\text { Calibration } \\
2004-2009\end{array}$ & $\begin{array}{l}\text { Validation } \\
\text { 2010-2012 }\end{array}$ \\
\hline Q observed & 9.31 & 9.80 & 8.82 & 5.23 & 5.95 & 4.12 \\
\hline Q simulated & 11.64 & 10.97 & 9.02 & 5.14 & 5.42 & 3.77 \\
\hline P-factor & 0.89 & 0.89 & 0.92 & 0.97 & 0.85 & 0.92 \\
\hline R-factor & 0.25 & 0.13 & 0.27 & 0.11 & 0.22 & 0.21 \\
\hline Nash-Sutcliffe efficiency & 0.90 & 0.88 & 0.87 & 0.82 & 0.84 & 0.68 \\
\hline
\end{tabular}



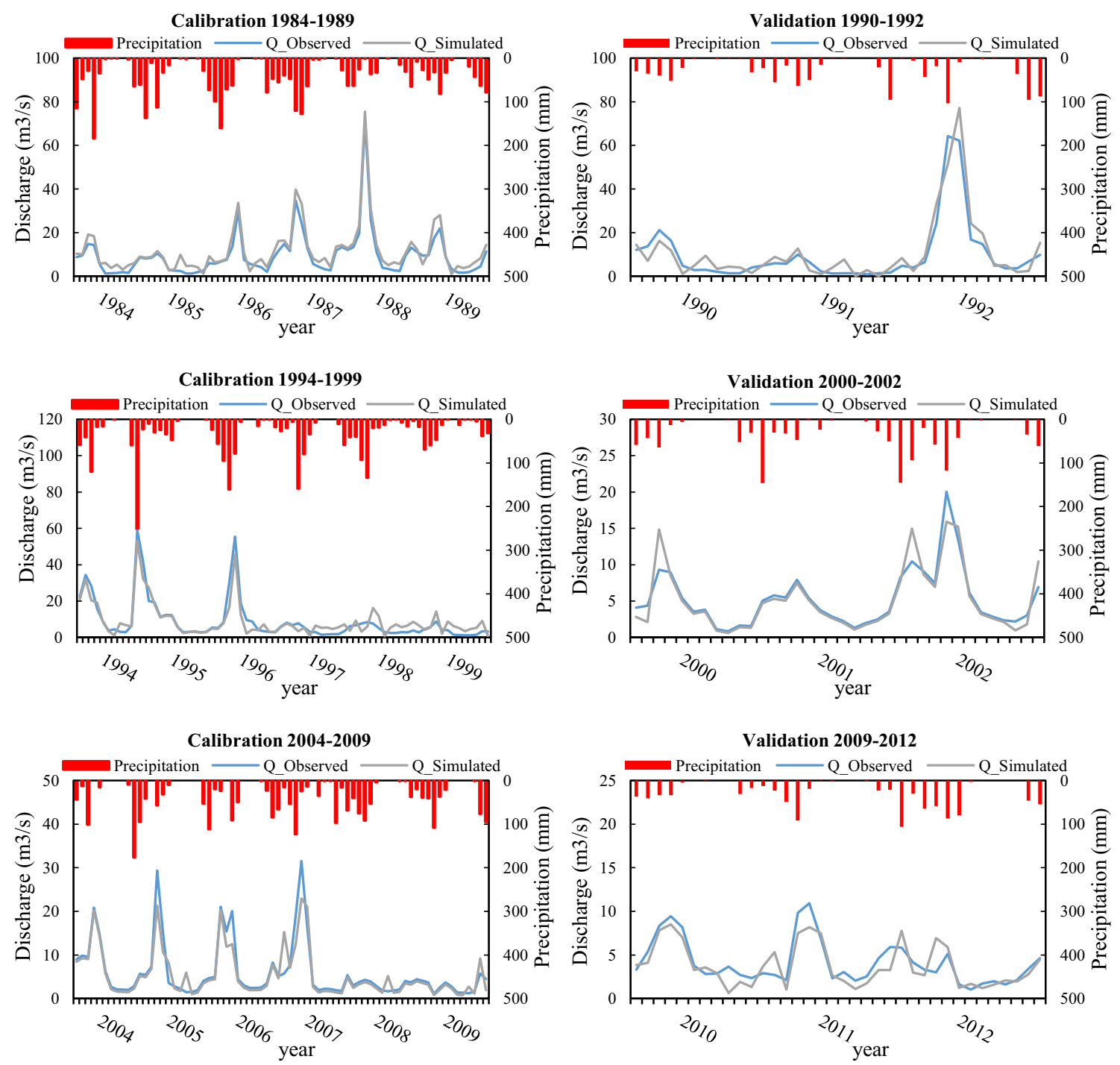

Fig. 3 Observed and simulated monthly discharge for (left) the calibration period and (right) the validation period used for the SWAT model

\subsection{Statistical Trend Analysis}

\subsubsection{Observed Hydro-climatological Trends (1983-2012)}

The seasonal Mann-Kendall test and Sen's slope indicator results showed that annual precipitation and discharge at the

Table 6 The six top-ranking sensitivity parameters and their initial and optimised (final) values (for parameter abbreviations, see text)

\begin{tabular}{ccccl}
\hline Parameters & $t$ value & $p$ value & Initial value & Optimised value \\
\hline r_CN2 & -6.93 & 0.00 & $-0.5,0.5$ & 0.18 \\
v-ALPHA_BF & -2.41 & 0.01 & 0,1 & 0.42 \\
v-ALPHA_BNK & -2.33 & 0.02 & 0,1 & 0.23 \\
r-SOL_K & -2.30 & 0.02 & $-0.8,0.8$ & 0.1 \\
r-SOL_BD & -2.21 & 0.03 & $-0.3,0.3$ & 0.09 \\
r-SOL_AWC & -1.98 & 0.04 & $-0.3,0.3$ & 0.02 \\
\hline
\end{tabular}

Aligudarz and Doroud stations decreased in significance in the Marboreh watershed during 1983-2012, while temperature at different time scales did not show a significant trend (Table 7 and Fig. 4). Seasonal Mann-Kendall test results for monthly scales revealed that January, February, March, April, May, June and December precipitation and January, February, March, April and December discharge decreased in significance during 1983-2012 (Table 7).

\subsubsection{Impacts of Land Use Change on Hydrological Indices}

The SWAT simulation using observed climate data and different land uses in the period 1982-2012 showed significant changes in hydrological indices for the different land use scenarios. In the first scenario (SR1: 30 years of observed data 1982-2012), annual high-flow pulse duration and wettest duration coefficient showed decreasing trends $(p<0.01)$. April low-flow and mean high-flow pulse duration per event also 
Table 7 Results of the Seasonal Mann-Kendall (SK) test and Sen's slope estimator (Sen) for monthly, seasonal and annual precipitation, temperature and discharge during 1983-2012

\begin{tabular}{|c|c|c|c|c|c|c|c|c|c|}
\hline \multirow[t]{2}{*}{ Time series } & \multicolumn{3}{|c|}{ Precipitation } & \multicolumn{3}{|c|}{ Temperature } & \multicolumn{3}{|c|}{ Discharge } \\
\hline & SK & $p$ value & Sen & SK & $p$ value & Sen & SK & $p$ value & Sen \\
\hline January & -1.909 & 0.026 & -2.161 & -0.161 & 0.872 & -0.008 & -3.515 & 0.000 & -0.239 \\
\hline February & -2.232 & 0.037 & -1.789 & -0.410 & 0.682 & -0.027 & -3.015 & 0.003 & -0.210 \\
\hline March & -1.846 & 0.041 & 2.024 & 0.607 & 0.544 & 0.017 & -2.409 & 0.016 & -0.421 \\
\hline April & -2.109 & 0.026 & -1.908 & -0.054 & 0.957 & -0.003 & -2.016 & 0.044 & -0.371 \\
\hline May & -2.353 & 0.030 & -1.838 & 1.445 & 0.148 & 0.032 & -1.802 & 0.072 & -0.239 \\
\hline June & -1.894 & 0.045 & -1.798 & 1.017 & 0.309 & 0.036 & -1.588 & 0.112 & -0.072 \\
\hline July & -1.109 & 0.268 & 0.000 & 0.839 & 0.402 & 0.016 & -1.695 & 0.090 & -0.066 \\
\hline August & -2.245 & 0.025 & 0.000 & -0.054 & 0.957 & -0.002 & -1.195 & 0.232 & -0.027 \\
\hline September & 0.495 & 0.620 & 0.000 & 1.302 & 0.193 & 0.029 & -0.767 & 0.443 & -0.019 \\
\hline October & -0.643 & 0.520 & -0.041 & 0.660 & 0.509 & 0.022 & -0.161 & 0.872 & -0.003 \\
\hline November & -0.446 & 0.656 & -0.283 & 1.499 & 0.134 & 0.029 & -1.624 & 0.104 & -0.088 \\
\hline December & 1.053 & 0.293 & 1.067 & 0.018 & 0.986 & 0.000 & -3.301 & 0.001 & -0.210 \\
\hline Winter & -2.117 & 0.022 & -2.931 & -0.232 & 0.817 & -0.009 & -2.979 & 0.003 & -0.301 \\
\hline Autumn & 0.339 & 0.735 & 0.203 & 0.089 & 0.929 & 0.004 & -2.016 & 0.044 & -0.077 \\
\hline Spring & -2.013 & 0.037 & -2.659 & 0.660 & 0.509 & 0.018 & -2.194 & 0.028 & -0.252 \\
\hline Summer & -1.118 & 0.263 & -0.004 & 1.231 & 0.218 & 0.022 & -1.017 & 0.309 & -0.033 \\
\hline Yearly & -2.124 & 0.026 & -2.942 & 0.696 & 0.487 & 0.007 & -2.444 & 0.015 & -0.178 \\
\hline
\end{tabular}

showed a decreasing trend $(p<0.05)$. All HDI decreased, while all LDIs showed an increasing trend, but this was not statistically significant (Table 8 and Fig. 5). In the second scenario (SR2: which assumed that land use in the second [1993-2002] and third periods [2003-2012] was similar to that in the first period [1983-1992]), low-flow pulse duration and driest duration coefficient (from LDI) showed increasing trends ( $p<0.01$ and $p<0.05$, respectively). Among the HDI, there were decreases in annual high-flow pulse duration, wettest duration coefficient $(p<0.01)$, minimum April-flow and

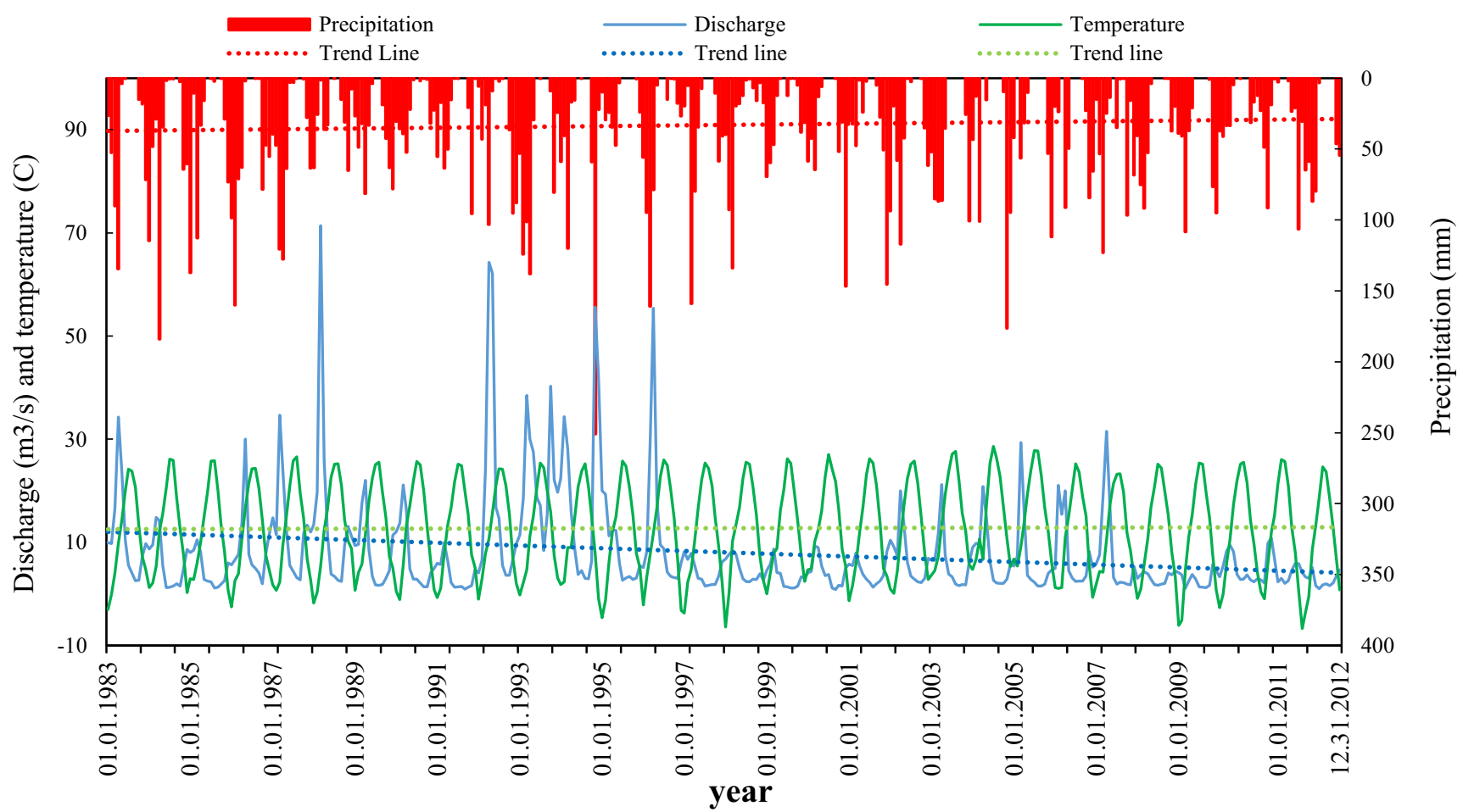

Fig. 4 Long-term trends in precipitation, temperature and discharge in the Marboreh watershed, 1983-2012 
Table 8 Results of the MannKendall (MK) test and Sen's slope estimator (Sen) for the historical (SR1) and land use (SR2) scenarios. $L D I$ low dependency indices, $H D I$ high dependency indices

\begin{tabular}{|c|c|c|c|c|c|c|}
\hline Indices & MK & $\begin{array}{l}p \\
\text { value }\end{array}$ & Sen & $\mathrm{M}-\mathrm{K}$ & $\begin{array}{l}p \\
\text { value }\end{array}$ & Sen \\
\hline & \multicolumn{3}{|c|}{ SR1 } & \multicolumn{3}{|c|}{ SR2 } \\
\hline Maximum September flow & -0.232 & 0.817 & 0.000 & -0.981 & 0.326 & -0.001 \\
\hline Low-flow pulse count & 1.752 & 0.080 & 0.107 & 1.814 & 0.070 & 0.125 \\
\hline Low-flow pulse duration & 1.625 & 0.104 & 2.111 & 2.964 & 0.003 & $5.056^{* *}$ \\
\hline Driest duration coefficient & 0.857 & 0.392 & 0.009 & 2.571 & 0.011 & $0.029 *$ \\
\hline Mean low-flow pulse duration per event & 0.393 & 0.694 & 0.148 & 1.500 & 0.134 & 0.455 \\
\hline Minimum April flow & -2.034 & 0.042 & $-0.008 *$ & -2.177 & 0.029 & $-0.008 *$ \\
\hline High-flow pulse count & -1.266 & 0.206 & -0.067 & -0.745 & 0.456 & 0.000 \\
\hline Annual high-flow pulse duration & -3.123 & 0.002 & $-4.667 * *$ & -3.195 & 0.001 & $-4.957 * *$ \\
\hline Wettest duration coefficient & -3.355 & 0.001 & $-0.032 * *$ & -3.069 & 0.002 & $-0.030 * *$ \\
\hline \multirow{2}{*}{$\begin{array}{l}\text { Mean high-flow pulse duration per } \\
\text { event }\end{array}$} & -2.267 & 0.023 & $-0.800^{*}$ & -2.445 & 0.014 & $-0.856^{*}$ \\
\hline & \multicolumn{3}{|c|}{ SR3 } & \multicolumn{3}{|c|}{ SR4 } \\
\hline Maximum September flow & -3.372 & 0.001 & $-0.004 * *$ & -1.731 & 0.084 & -0.003 \\
\hline Low-flow pulse count & 2.015 & 0.044 & 0.130 & 4.383 & 0.000 & $0.182 * *$ \\
\hline Low-flow pulse duration & 3.524 & 0.000 & $4.900 * *$ & 4.333 & 0.000 & $4.500 * *$ \\
\hline Driest duration coefficient & 2.987 & 0.003 & $0.028 * *$ & 4.333 & 0.000 & $0.023 * *$ \\
\hline Mean low-flow pulse duration per event & 2.362 & 0.018 & $0.942 * *$ & 3.532 & 0.000 & $0.643 * *$ \\
\hline Minimum April flow & -2.320 & 0.020 & $-0.008 *$ & -2.248 & 0.025 & $-0.009 *$ \\
\hline High-flow pulse count & -1.593 & 0.111 & -0.074 & -3.213 & 0.001 & $-0.182 * *$ \\
\hline Annual high-flow pulse duration & -3.444 & 0.001 & $-5.533 * *$ & -3.607 & 0.000 & $-6.130 * *$ \\
\hline Wettest duration coefficient & -3.069 & 0.002 & $-0.025^{* *}$ & -3.497 & 0.000 & $-0.037 * *$ \\
\hline $\begin{array}{l}\text { Mean high-flow pulse duration per } \\
\text { event }\end{array}$ & -2.606 & 0.009 & $-0.906 * *$ & -3.052 & 0.002 & $-1.406^{* *}$ \\
\hline
\end{tabular}

Italic value indicate the significant trend

*, ** indicate $5 \%$ and $1 \%$ significance level, respectively mean high-flow pulse duration per event $(p<0.05)$ (Table 7 and Fig. 5). In scenarios SR3 and SR4, where land use in the second (1993-2002) and third (2003-2012) period was assumed as the land use of the whole 30-year study period, all LDI, except maximum September flow, showed increasing trends, while all HDI showed decreasing trends, at different levels of significance (Table 8, Fig. 5).

\subsubsection{Impacts of Climate Change on Hydrological Indices}

Scenario settings for different decadal climate periods showed that climate change influenced the hydrological index trends more than land use changes in the Marboreh watershed. Statistical test results for climate scenarios SR5, SR6 and SR7 were as follows: In SR5, all LDI (except maximum September flow) showed a decreasing trend $(p<0.01)$, while HDI showed non-significant increasing trends for minimum low flow during the wettest month (MLF), high-flow pulse duration (HPD) and mean high-flow pulse duration per event (MHPD) and non-significant decreasing trends for number of high-flow pulse counts per year (HPC) and wetness duration coefficient (WDC). In scenario SR6, all LDI increased (not significantly) and all HDI (except HPC) decreased, although not significantly. In scenario R7, all LDI (except mean lowflow pulse duration per event (MLPD) increased (not significantly) and all HDI (except HPC) decreased non-significantly (Table 9 and Fig. 6).

\subsection{Comparison Scenarios Based on Hydrological Indices}

Based on the number of altered indices (with significance level, using $t$ test), the scenarios were ranked in the order SR7 (with most variation in climate), SR5, SR4 (with most changes in land use) and SR6, with seven, six, three and one out of 10 altered indices, respectively (Table 10). For two other land use scenarios (SR2 and SR3), the results indicated no significance changes in hydrological indices. In land use scenario SR4, the number of low-flow pulse counts per year (LPC), annual low-flow pulse duration (LPD) and dryness duration coefficient (DDC) showed alterations $(p<0.05)$, but there was no significance alteration in other LDI or in all HDI (Table 10). 
Fig. 5 Long-term trends in different hydrological indices under different land use and historical scenarios (SR1-4). P.C. pulse count, P.D. pulse duration, L(H).F.D./N.D) low (high)-flow duration/normal day (low (left panel) high (right panel)

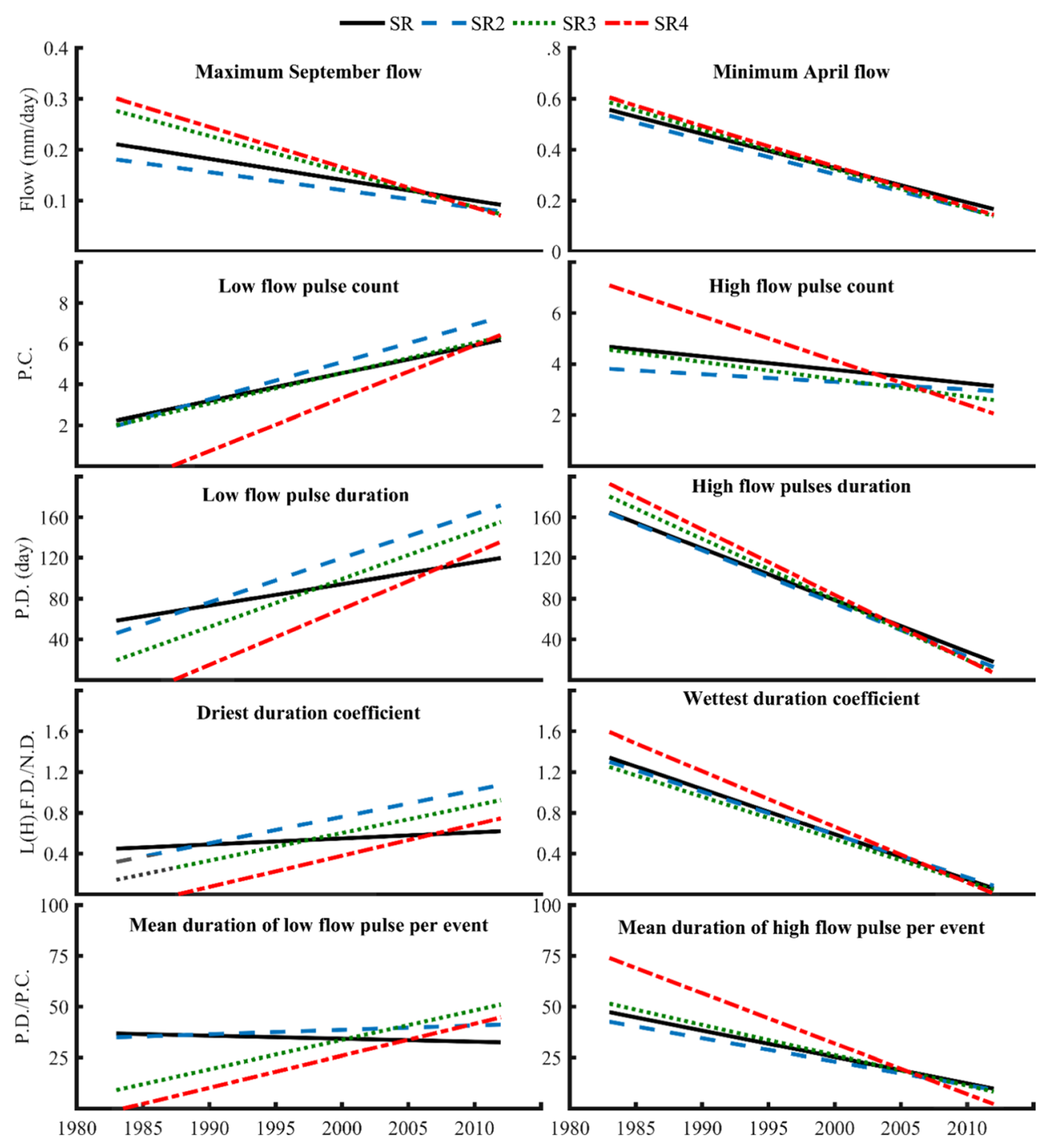

Of all the hydrological indices tested, DDC showed the highest sensitivity to both climate change and LULCC, while MHPD showed the lowest sensitivity. In the land use and climate scenarios, LDI showed more changes than HDI. With increasing change in land use (from SR2 to SR4), LDI values decreased (except MLF), while HDI values increased (except WDC) (Fig. 7). With climate shifts (from SR5 to SR7), LDI values increased (except MLF), while HDI values decreased (Fig. 7 and Table 8).

\section{Discussion}

In recent decades, land use changes have been rapid in many developing semi-arid regions such as Iran, which has affected water flow regimes significantly [22]. In the area examined in the present study, the main land use changes were an increase in rainfed agricultural area in the catchment $(+14.66 \%)$ and a decrease in rangeland area $(-18.4 \%)$. These changes did not seem to have affected the hydrological indicators studied, however. This is important, as a reduction in flow would be problematic because the Marboreh watershed is an important source of hydropower energy in Iran [52]. Land use mapping, which influenced the results, depends on many factors, such as research target, landscape complexity and scale, which are usually predetermined by the user's requirements. This study focused on analysis of some of the factors that can be controlled, to improve classification accuracy and prepare for land use mapping based on the ground trust. The results obtained for the Marboreh watershed show that the land use changes from 1988 to 2008 have been associated with degradation of natural resources.

Two driving forces, LULCC and climate change, affect hydrological conditions. Distinguishing the long-term changes in hydrological conditions caused by the separate and combined impacts of LULCC and climate change is crucial for sustainable water resource planning. Some previous studies have assessed the relative impacts of LULCC and climate change on stream flow in watersheds (e.g. [18, 
Table 9 Results of the MannKendall (MK) test and Sen's slope estimator (Sen) for hydrological indicators used in (upper section) the historical scenario (SR1) and climate scenario SR5; and (lower section) climate scenarios SR6 and SR7. $L D I$ low dependency indices, $H D I$ high dependency indices

\begin{tabular}{|c|c|c|c|c|c|c|}
\hline Indices & MK & $\begin{array}{l}p \\
\text { value }\end{array}$ & Sen & MK & $\begin{array}{l}p \\
\text { value }\end{array}$ & Sen \\
\hline & \multicolumn{3}{|c|}{ SR1 } & \multicolumn{3}{|c|}{ SR5 } \\
\hline Maximum September flow & -0.232 & 0.817 & 0.000 & -0.375 & 0.708 & -0.001 \\
\hline Low-flow pulse count & 1.752 & 0.080 & 0.107 & -2.658 & 0.008 & $-0.071 * *$ \\
\hline Low-flow pulse duration & 1.625 & 0.104 & 2.111 & -2.841 & 0.004 & $-0.923 * *$ \\
\hline Driest duration coefficient & 0.857 & 0.392 & 0.009 & -3.043 & 0.002 & $-0.007 * *$ \\
\hline Mean low-flow pulse duration per event & 0.393 & 0.694 & 0.148 & -2.750 & 0.006 & $-0.462 * *$ \\
\hline Maximum September flow & -2.034 & 0.042 & $-0.008 *$ & 0.339 & 0.735 & 0.001 \\
\hline Low-flow pulse count & -1.266 & 0.206 & -0.067 & -1.608 & 0.108 & -0.091 \\
\hline Low-flow pulse duration & -3.123 & 0.002 & $-4.667 * *$ & 0.393 & 0.695 & 0.526 \\
\hline Driest duration coefficient & -3.355 & 0.001 & $-0.032 * *$ & -0.553 & 0.580 & -0.006 \\
\hline Mean low-flow pulse duration per event & \multicolumn{3}{|c|}{ SR6 } & \multicolumn{2}{|r|}{ SR7 } & 0.795 \\
\hline Maximum September flow & 1.195 & 0.232 & 0.002 & 0.785 & 0.432 & 0.001 \\
\hline Low-flow pulse count & -0.722 & 0.470 & 0.000 & 1.078 & 0.281 & 0.067 \\
\hline Low-flow pulse duration & 0.162 & 0.872 & 0.000 & 1.499 & 0.134 & 1.235 \\
\hline Driest duration coefficient & 0.072 & 0.943 & 0.000 & 1.017 & 0.309 & 0.009 \\
\hline Mean low-flow pulse duration per event & 0.539 & 0.590 & 0.056 & -0.143 & 0.886 & -0.043 \\
\hline Minimum April flow & -0.731 & 0.464 & -0.002 & -1.320 & 0.187 & -0.003 \\
\hline High-flow pulse count & -0.018 & 0.985 & 0.000 & -0.507 & 0.612 & 0.000 \\
\hline Annual high-flow pulse duration & -1.698 & 0.090 & -0.889 & -0.915 & 0.360 & -0.400 \\
\hline Wettest duration coefficient & -1.803 & 0.071 & -0.006 & -0.789 & 0.430 & -0.003 \\
\hline $\begin{array}{l}\text { Mean high-flow pulse duration per } \\
\text { event }\end{array}$ & -1.519 & 0.129 & -0.375 & -1.295 & 0.195 & -0.294 \\
\hline
\end{tabular}

Italic value indicate the significant trend

*, ** indicate $5 \%$ and $1 \%$ significance level, respectively
$26,36,46,76,77])$. Ward et al. [67] concluded that, by the end of the twentieth century, LULCC had had more serious effects than climate change on hydrological conditions, while over the early decades of the twenty-first century climate change became more important. In the present study, catchment sensitivity to LULCC and climate change was assessed in a scenario-based approach by comparing responses in 10 hydrological indices in the Marboreh watershed, Iran. It should be noted that identifying the combined impacts of land use and climate changes on hydrological conditions is complex. Some studies have examined the interactions between land use and climate change on hydrological conditions $[16,57,77]$, but there is a large amount of uncertainty in the results and more scientific investigation is needed. In this study, we attempted to quantify the hydrological impacts of land use change and climate change using the $t$ test method. The results revealed that climate change affected the hydrological indices studied more significantly than land use change, particularly in the case of low dependency indices (there were more significant changes in 10 hydrological indices under the climate scenarios than under the land use change scenarios). Overall, our analysis revealed that climate change over a period of 30 years (through natural climate variation and/ or human-induced global) can have a stronger effect than LULCC on hydrological indices in semi-arid headwater regions such as the study area. However, this finding can partly depend on the limited length of the study period and the occurrence of wet conditions in the early part of the period and dry conditions in recent years. Further observations and studies are need to confirm long-term hydrological trends in the region.

Future analysis could also consider future land use changes (by applying a LULCC model, e.g. Land Change Modeller (LCM), or climate change scenarios when predicting hydrological changes in this basin). Although our framework contains several uncertainties, e.g. using SWAT as a hydrological model, the uncertainty lies mainly in the daily climatological data and the use of one LULC map for each decade [28, 57]. However, due to the use of current data and the fact that climate models, downscaling, emission scenarios and hydrological modelling for future periods are not needed, a large number of uncertainty sources are eliminated from the impact analysis. Moreover, other hydrological indices could be used (e.g. an indicator of hydrological alteration) to obtain better resolution in identifying the sensitivity to LULCC and climate change. 
Fig. 6 Long-term trends in different hydrological indices under different land use and historical scenarios (SR1 and SR5-7). P.C. pulse count, P.D. pulse duration, L(H).F.D./N.D) low (high)-flow duration/normal day (low (left panel) high (right panel)

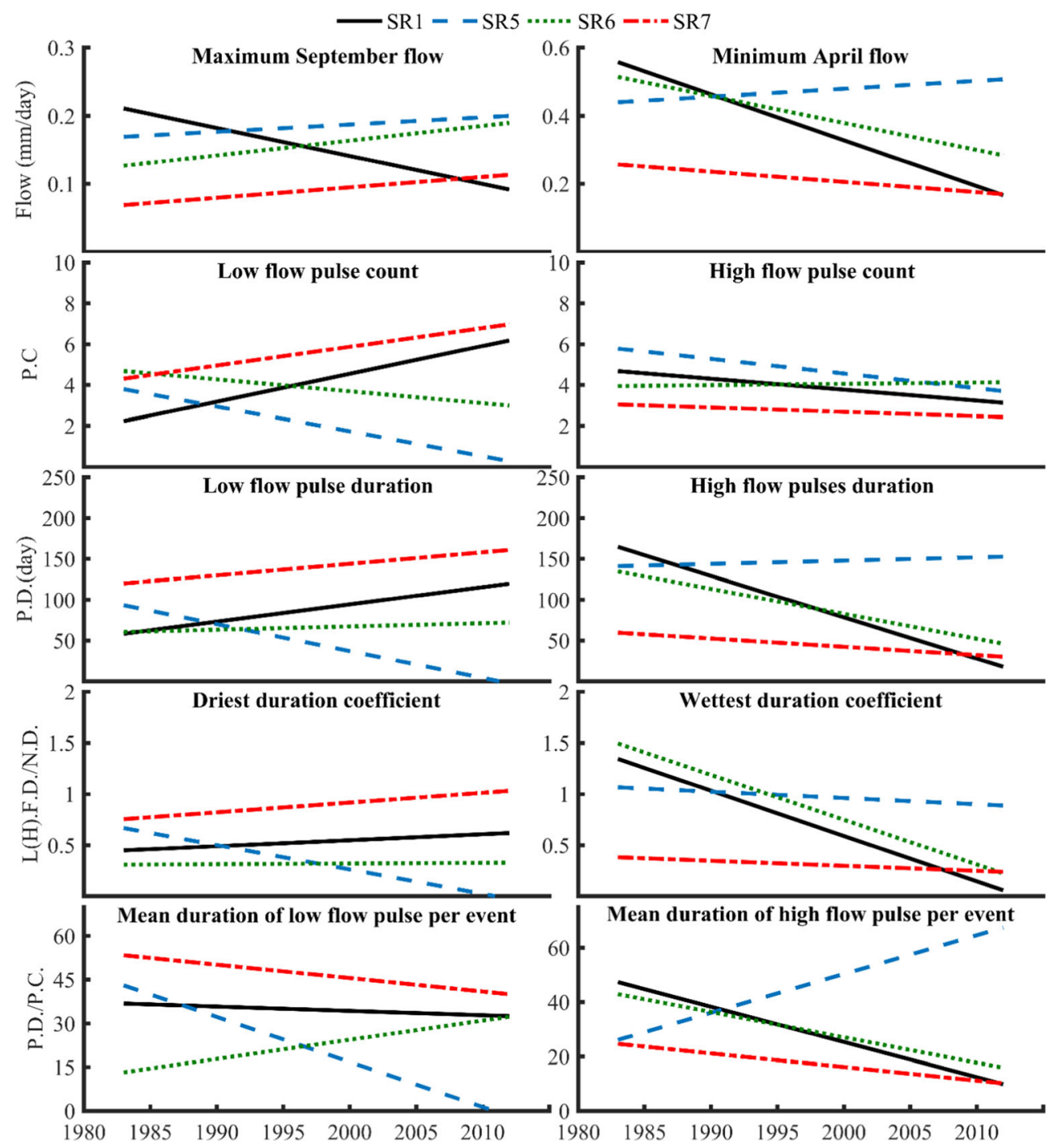

\section{Conclusions}

Watershed hydrological responses to the impact of land use/ land cover change (LULCC) and climate change were assessed with SWAT modelling based on the three different types of scenario (historical, land use, climate). The results showed minor changes in hydrology due to land use change from rangeland to rainfed agriculture. These were accompanied by smaller changes in irrigated area in the Marboreh watershed compared with other regions in Iran in the period,

Table 10 Comparison of mean hydrological index results obtained using $t$ test for scenarios SR1-SR7 (for index abbreviations, see Table 4)

\begin{tabular}{|c|c|c|c|c|c|c|c|c|c|c|}
\hline & \multicolumn{5}{|c|}{ Low dependency indices (LDI) } & \multicolumn{5}{|c|}{ High dependency indices (HDI) } \\
\hline & MLF & LPC & LPD & $\mathrm{DDC}$ & MLPD & MHF & HPC & HPD & WDC & MHPD \\
\hline SR1-SR2 & 0.186 & 0.491 & 0.061 & 0.065 & 0.445 & 0.052 & 0.164 & 0.064 & 0.704 & 0.351 \\
\hline SR1-SR3 & 0.214 & 0.947 & 0.758 & 0.983 & 0.481 & 0.981 & 0.277 & 0.292 & 0.155 & 0.444 \\
\hline SR1-SR4 & 0.062 & $0.002 * *$ & $0.002 * *$ & $0.005 * *$ & 0.115 & 0.122 & 0.12 & 0.053 & 0.063 & 0.056 \\
\hline SR1-SR5 & 0.557 & $0.003 * *$ & $0.003 * *$ & $0.023 *$ & $0.037 *$ & 0.122 & 0.057 & $0.002 * *$ & $0.029 *$ & 0.087 \\
\hline SR1-SR6 & 0.896 & 0.623 & 0.107 & $0.021 *$ & 0.277 & 0.643 & 0.769 & 0.963 & 0.527 & 0.92 \\
\hline SR1-SR7 & $0.032 *$ & 0.103 & $0.000 * *$ & $0.001 * *$ & 0.274 & $0.036^{*}$ & $0.029 *$ & $0.003 * *$ & $0.003 * *$ & 0.094 \\
\hline
\end{tabular}

$* p<0.05, * * p<0.01$ 
Fig. 7 Changes in different hydrological indices in scenarios SR1-SR7 during the 30-year study period. ${ }^{*} p<0.05$, $* * p<0.01$

$$
\text { 章 }
$$
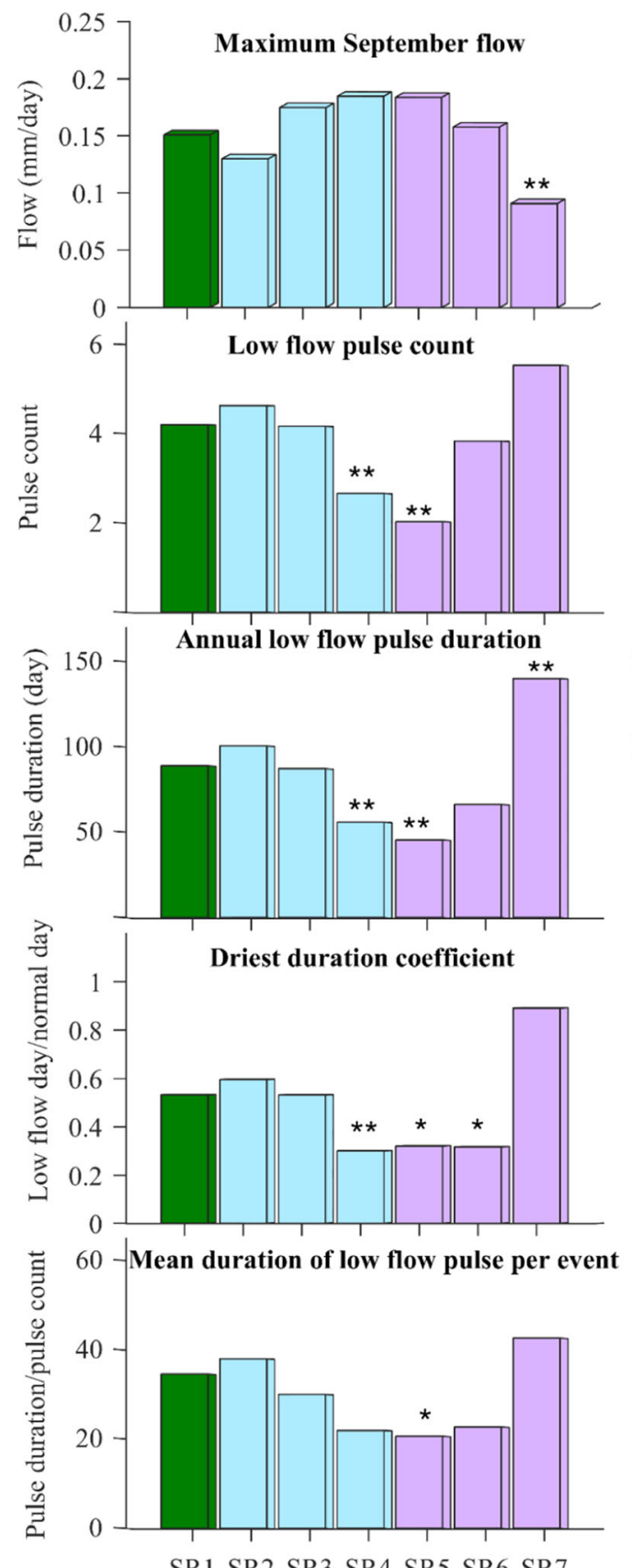

SR1 SR2 SR3 SR4 SR5 SR6 SR7
Land use Scenarios $\square$ Climate scenarios
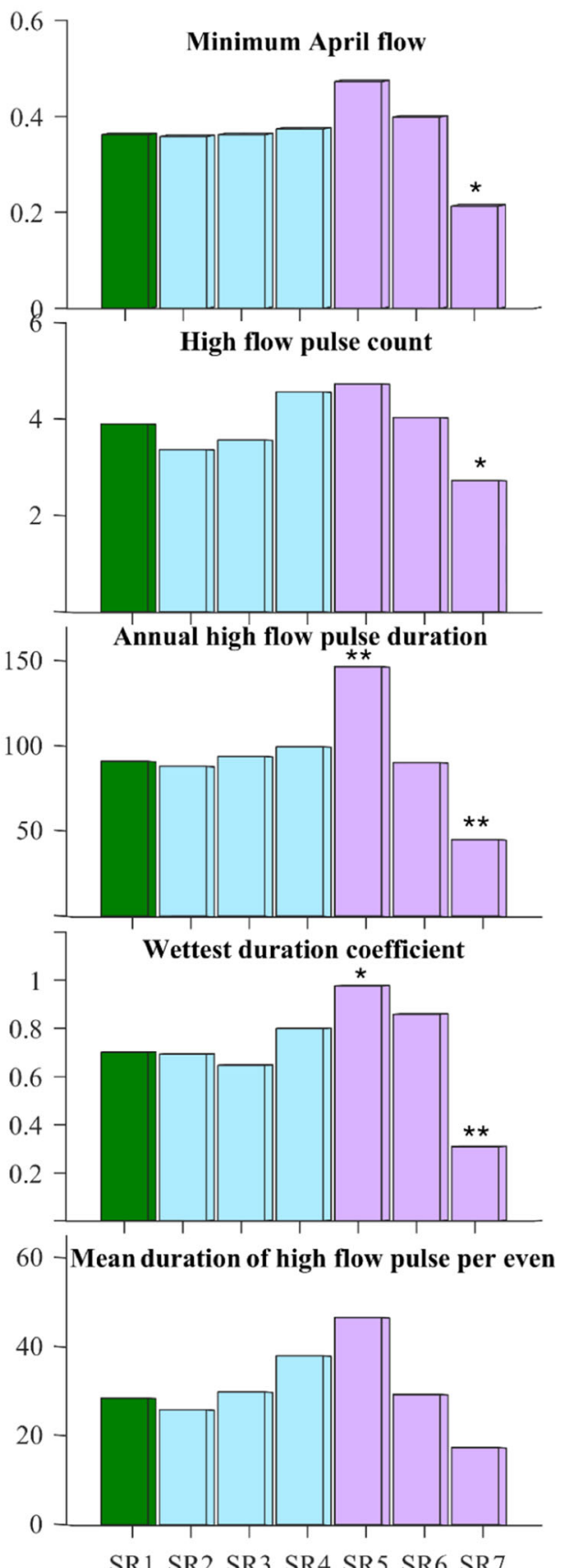

owing to the headwater and mountainous characteristics of the watershed.

The main driver of hydrological changes in the Marboreh watershed was thus climate change, caused by natural variability and/or anthropogenic changes. In the period 19832012, the basin became drier due to less annual precipitation and runoff and this drying effect influenced the trend slopes of hydrological indices more significantly than LULCC in the watershed in the same period.
Acknowledgements Open access funding provided by University of Oulu including Oulu University Hospital.

Open Access This article is distributed under the terms of the Creative Commons Attribution 4.0 International License (http:// creativecommons.org/licenses/by/4.0/), which permits unrestricted use, distribution, and reproduction in any medium, provided you give appropriate credit to the original author(s) and the source, provide a link to the Creative Commons license, and indicate if changes were made. 


\section{References}

1. Abbaspour, K. C., Rouholahnejad, E., Vaghefi, S., Srinivasan, R., Yang, H., \& Klove, B. (2015). A continental-scale hydrology and water quality model for Europe: calibration and uncertainty of a high-resolution large-scale SWAT model. Journal of Hydrology, 524, 733-752.

2. Amin, M. Z. M., Shaaban, A. J., Ercan, A., Ishida, K., Kavvas, M. L., \& Chen, Z. Q. S. (2017). JangFuture climate change impact assessment of watershed scale hydrologic processes in Peninsular Malaysia by a regional climate model coupled with a physically-based hydrology models. Science of the Total Environment, 575, 12-22.

3. Arnell, N. W., van Vuuren, D. P., \& Isaac, M. (2011). The implications of climate policy for the impacts of climate change on global water resources. Global Environmental Change, 21(2), 592-603.

4. Arnold, J. G., Srinivasan, R., Muttiah, R. S., \& Williams, J. R. (1998). Large area hydrologic modeling and assessment. Part 1: model development. Journal of the American Water Resources Association, 34, 73-89.

5. Ashraf, F. B., Torabi Haghighi, A., Marttila, H., \& Kløve, B. (2016). Assessing impacts of climate change and river regulation on flow regimes in cold climate: a study of a pristine and a regulated river in the sub-arctic setting of northern Europe. Journal of Hydrology, 542, 410-422.

6. Bangash, R. F., Passuello, A., Sanchez-Canales, M., Terrado, M., López, A., Elorza, F. J., Ziv, G., Acuña, V., \& Schuhmacher, M. (2013). Ecosystem services in Mediterranean river basin: climate change impact on water provisioning and erosion control. Science of the Total Environment, 458-460, 246-255.

7. Bradley, A. P. (1997). The use of the area under the ROC curve in the evaluation of machine learning algorithms. Pattern Recognition, 30, 1145-1159.

8. Dams, J., Nossent, J., Senbeta, T. B., Willems, P., \& Batelaan, O. (2015). Multi-model approach to assess the impact of climate change on runoff. Joural of Hydrology, 529, 1601-1616.

9. Darabi, H., Choubin, B., Rahmati, O., Haghighi, A. T., Pradhan, B., \& Kløve, B. (2019). Urban flood risk mapping using the GARP and QUEST models: a comparative study of machine learning techniques. Journal of Hydrology, 569, 142-154.

10. Darabi, H., Shahedi, K., Solaimani, K., \& Miryaghoubzadeh, M. (2014). Prioritization of subwatersheds based on flooding conditions using hydrological model, multivariate analysis and remote sensing technique. Water and Environmental. Journal., 28, 382-392.

11. Das, T. (2009). Land use/land cover change detection: an object oriented approach, Thesis: Master of Science in Geospatial Technologies, Institute for Geoinformatics, University of Münster, $70 \mathrm{pp}$.

12. El-Khoury, A., Seidou, O., Lapen, D. R., Que, Z., Mohammadian, M., Sunohara, M., \& Bahram, D. (2015). Combined impacts of future climate and land use changes on discharge, nitrogen and phosphorus loads for a Canadian river basin. Journal of Environmental Management, 151, 76-86.

13. Ertürk, A., Ekdal, A., Gürel, M., Karakaya, N., Guzel, C., \& Gönenç, E. (2014). Evaluating the impact of climate change on groundwater resources in a small Mediterranean watershed. Science of the Total Environment, 499(15), 437-447.

14. Fan, M., Shibata, H., \& Wang, Q. (2016). Optimal conservation planning of multiple hydrological ecosystem services under land use and climate changes in Teshio river watershed, northernmost of Japan. Ecological Indicators, 62, 1-13.

15. FAO. (1995). The digital soil map of the world and derived soil properties. Rome: FAO.

16. Faramarzi, M., Abbaspour, K. C., Schulin, R., \& Yang, H. (2009). Modelling blue and green water resources availability in Iran. Hydrological Processes: An International Journal, 23(3), 486-501.
17. Gocic, M., \& Trajkovic, S. (2013). Analysis of changes in meteorological variables using Mann-Kendall and Sen's slope estimator statistical tests in Serbia. Global and Planetary Change, 100, 172-182.

18. Gohar, A. A., \& Cashman, A. (2016). A methodology to assess the impact of climate variability and change on water resources, food security and economic welfare. Agricultural Systems, 147, 51-64.

19. Hamed, K. H. (2008). Trend detection in hydrologic data: the Mann-Kendall trend test under the scaling hypothesis. Journal of Hydrology, 349, 350-363.

20. Hartmann, H., Snow, J. A., Sub, B., \& Jiang, T. (2016). Seasonal predictions of precipitation in the Aksu-Tarim River basin for improved water resources management. Global and Planetary Change, 147, 86-96.

21. Hefzul Bari, S., Rahman, T. U., Hoque Azizul, M., \& Hussain, M. (2016). Analysis of seasonal and annual rainfall trends in the northern region of Bangladesh. Atmospheric Research, 176-177(1), $148-158$.

22. Hosseini, M., \& Ashraf, M. A. (2015). Application of the SWAT model for water components separation in Iran. Springer Hydrogeology, 1-32. https://doi.org/10.1007/978-4-431-55564-3-2.

23. Kalantari, Z., Lyon, S. W., Folkeson, L., French, H. K., Stolte, J., Jansson, P. E., \& Sassner, M. (2014). Quantifying the hydrological impact of simulated changes in land use on peak discharge in a small catchment. Science of the Total Environment, 466-467, 741-754.

24. Karlsson, I. B., Sonnenborg, T. O., Refsgaard, J. C., Trolle, D., Børgesen, C. D., Olesen, J. E., Jeppesen, E., \& Jensen, K. H. (2016). Combined effects of climate models, hydrological model structures and land use scenarios on hydrological impacts of climate change. Journal of Hydrololy., 535, 301-317.

25. Khoi, D. N., \& Suetsugi, T. (2014). The responses of hydrological processes and sediment yield to land-use and climate change in the Be River Catchment, Vietnam. Hydrological Processes, 28, 640-652.

26. Kim, J., Choi, J., Choi, C., \& Park, S. (2013). Impacts of changes in climate and land use/land cover IPCC RCP scenarios on streamflow in the Hoeya River Basin, Korea. Science of the Total Environment, 452-453, 181-195.

27. Koutroulis, A. G., Tsanis, I. K., Daliakopoulos, I. N., \& Jacob, D. (2013). Impact of climate change on water resources status: a case study for Crete Island, Greece. Journal of Hydrology, 479, 146-158.

28. Lespinas, F., Ludwig, W., \& Heussner, S. (2014). Hydrological and climatic uncertainties associated with modeling the impact of climate change on water resources of small Mediterranean coastal rivers. Journal of Hydrology, 511, 403-422.

29. Li, Z., Liu, W. Z., Zhang, X. C., \& Zheng, F. L. (2009). Impacts of land use change and climate variability on hydrology in an agricultural catchment on the Loess Plateau of China. Journal of Hydrology, 377(1), 35-42.

30. Liang, S., Fang, H., \& Chen, M. (2001). Atmospheric correction of Landsat ETM+ land surface imagery. I. Methods. IEEE Trans. Geoscience and Remote Sensing, 39(11), 2490-2498.

31. Lu, H., Bryant, R. B., Buda, A. R., Collick, A. S., Folmar, G. J., \& Kleinman, P. J. A. (2015). Long-term trends in climate and hydrology in an agricultural, headwater watershed of central Pennsylvania, USA. Journal of Hydrology: Regional Studies, 4, 713-731.

32. Luo, Y., Ficklin, D. L., Liu, X., \& Zhang, M. (2013). Assessment of climate change impacts on hydrology and water quality with a watershed modeling approach. Science of the Total Environment, 450-451, $72-82$.

33. Magilligan, F. J., \& Nislow, K. H. (2005). Changes in hydrologic regime by dams. Geomorphology, 71, 61-78.

34. Mango, L. M., Melesse, A. M., McClain, M. E., Gann, D., \& Setegn, S. G. (2011). Land use and climate change impacts on the hydrology of the upper Mara River Basin, Kenya: results of a modeling study to support better resource management. Hydrology and Earth System Sciences, 15, 2245-2258. 
35. Mathews, R., \& Richter, B. D. (2007). Application of the indicators of hydrologic alteration software in environmental flow setting. Journal of the American Water Resources Association, 43(6), $1400-1413$.

36. Meng, F., Su, F., Yang, D., Tong, K., \& Hao, Z. (2016). Impacts of recent climate change on the hydrology in the source region of the Yellow River basin. Journal of Hydrology: Regional Studies, 6, 66-81.

37. Montenegro, S., \& Ragab, R. (2012). Impact of possible climate and land use changes in the semi-arid regions: a case study from north eastern Brazil. Journal of Hydrology, 434-435, 55-68.

38. Mosammadian, H. M., Nia, J. T., Khani, H., Teymouri, A., \& Kazemi, M. (2017). Monitoring land use change and measuring urban sprawl based on its spatial forms: the case of Qom city. The Egyptian Journal of Remote Sensing and Space Science, 20(1), 103-116.

39. Mourato, S., Moreira, M., \& Corte-Real, J. (2015). Water resources impact assessment under climate change scenarios in Mediterranean watersheds, Water Resources. Management, 109(7), 2377-2391.

40. Nash, J. E., \& Sutcliffe, J. V. (1970). River flow forecasting through conceptual models, Part I- A discussion of principles. Journal of Hydrology, 10, 282-290.

41. Neitsch, S. L., Arnold, J. G., Kiniry, J. R., \& Williams, J. R. (2011). Soil and water assessment tool theoretical documentation. Version 2009. Texas: Texas Water Resources Institute Technical Report No. 406. Texas A\&M University System.

42. Niehoff, D., Fritsch, U., \& Bronestert, A. (2002). Land use impacts on storm-runoff generation: scenario of land use change and simulation of hydrological response in a meso-scale catchment in SWGermany. Journal of Hydrology, 267(1-2), 80-93.

43. Olden, J. D., \& Poff, N. L. (2003). Redundancy and the choice of hydrologic indices for characterizing streamflow regimes. River Research and Applications, 19, 101-121.

44. Palazón, L., \& Navas, A. (2016). Land use sediment production response under different climatic conditions in an alpineprealpine catchment. Catena, 137, 244-255.

45. Perilla, O. L. U., Gomez, A. G., Gomez, A. G., Diaz, C. A., \& Cortezon, J. A. R. (2012). Methodology to assess sustainable management of water resources in coastal lagoons with agricultural uses: an application to the Albufera lagoon of Valencia (eastern Spain). Ecological Indicators, 13, 129-143.

46. Perveza, M. S., \& Henebry, G. M. (2015). Assessing the impacts of climate and land use and land cover change on the freshwater availability in the Brahmaputra River basin. Journal of Hydrology: Regional Studies, 3, 285-311.

47. Pirnia, A., Golshan, M., Darabi, H., Adamowski, J., \& Rozbeh, S. (2018). Using the Mann-Kendall test and double mass curve method to explore stream flow changes in response to climate and human activities. Journal of Water and Climate Change, 162, 1-18.

48. Pullanikkatil, D., Palamuleni, L., \& Ruhiiga, T. (2016). Assessment of land use change in Likangala River catchment, Malawi: a remote sensing and DPSIR approach. Applied Geography, 71, 9-23.

49. Rahman, K., Silva, A. G., Moran, E. T., Gobiet, A., Beniston, M., \& Lehmann, A. (2015). An independent and combined effect analysis of land use and climate change in the upper Rhone River watershed, Switzerland. Applied Geography, 63, 264-272.

50. Rosmanna, T., Domíngueza, E., \& Chavarro, J. (2015). Comparing trends in hydro-meteorological average and extreme data sets around the world at different time scales. Journal of Hydrology: Regional Studies, 5, 200-212.

51. Sahin, S. (2012). An aridity index defined by precipitation and specific humidity. Journal of Hydrology, 444-445, 199-208.

52. Samadi Boroujeni, H. (2012). Sediment management in hydropower dam (Case Study: Dez Dam project), Hydropower - Practice and Application. ISBN: 978-953-51-0164-2, 29 pp.
53. Sang, Y. F., Wang, Z., \& Liu, C. (2014). Comparison of the MK test and EMD method for trend identification in hydrological time series. Journal of Hydrology, 510, 293-298.

54. Serpa, D., Nunes, J. P., Santos, J., Sampaio, E., Jacinto, R., Veiga, S., Lima, J. C., Moreira, M., Corte-Real, J., Keizer, J. J., \& Abrantes, N. (2015). Impacts of climate and land use changes on the hydrological and erosion processes of two contrasting Mediterranean catchments. Science of the Total Environment, 538, 64-77.

55. Seung-Hwan, Y., Jin-Yong, C., Sang-Hyun, L., Yun-Gyeong, O., \& Dong Koun, Y. (2013). Climate change impacts on water storage requirements of an agricultural reservoir considering changes in land use and rice growing season in Korea. Agricultural Water Management, 117, 43-54.

56. Shamir, E., Megdal, S. B., Carrillo, C., Castro, C. L., Chang, H. I., Chief, K., Corkhill, F. E., E, S., Georgakakos, K. P., Nelson, K. M., \& Jacob, P. (2015). Clim. change and water resources management in the Upper Santa Cruz River, Arizona. Journal of Hydrology, 521, 18-33.

57. Singh, R., Wagener, T., Crane, R., Mann, M. E., \& Ning, L. (2014). A vulnerability driven approach to identify adverse climate and land use change combinations for critical hydrologic indicator thresholds: application to a watershed in Pennsylvania, USA. Water Resources Research, 50, 3409-3427.

58. Su, B., Huang, J., Gemmer, M., Jian, D., Tao, H., Jiang, T., \& Zhao, C. (2016). Statistical downscaling of CMIP5 multi-model ensemble for projected changes of climate in the Indus River Basin. Atmospheric Research, 178-179, 138-149.

59. Sun, L., Nistor, I., \& Seidou, O. (2015). Streamflow data assimilation in SWAT model using Extended Kalman Filter. Journal of Hydrology, 531, 671-684.

60. Tong, S. T., Sun, Y., Ranatunga, T., He, J., \& Yang, Y. J. (2012). Predicting plausible impacts of sets of climate and land use change scenarios on water resources. Applied Geography, 32, 477-489.

61. Torabi Haghighi, A., \& Kløve, B. (2015). A sensitivity analysis of Lake water level response to changes in climate and river regimes. Limnologica-Ecology and Management of Inland Waters, 51, 118130 .

62. Torabi Haghighi, A., Marttila, H., \& Kløve, B. (2014). Development of a new index to assess river regime impacts after dam construction. Global and Planetary Change, 122, 186-196.

63. Torabi Haghighi, A., Menberu, M. W., Darabi, H., Akanegbu, J., \& Kløve, B. (2018). Use of remote sensing to analyse peatland changes after drainage for peat extraction. Land Degradation \& Development, 29(10), 3479-3488.

64. Trang, N. T. T., Shrestha, S., Shrestha, M., Datta, A., \& Akiyuki, K. (2017). Evaluating the impacts of climate and land-use change on the hydrology and nutrient yield in a transboundary river basin: a case study in the $3 \mathrm{~S}$ River Basin (Sekong, Sesan, and Srepok). Science of the Total Environment, 576, 586-598.

65. Tsanis, I. K., Koutroulis, A. G., Daliakopoulos, I. N., \& Jacob, D. (2011). Severe climate induced water shortage and extremes in Crete. Climate Change, 106(4), 667-677.

66. Warburton, M. L., Schulze, R. E., \& Jewitt, G. P. W. (2012), Hydrological impacts of land use change in three diverse South African catchments. Journal of Hydrology, 414-415, 118-135.

67. Ward, P. J., Renssen, H., Aerts, J. C. J. H., van Balen, R. T., \& Vandenberghe, J. (2008). Strong increases in flood frequency and discharge of the River Meuse over the late Holocene: impacts of long-term anthropogenic land use change and climate variability. Hydrology and Earth System Sciences, 12, 159-175.

68. Welde, K., \& Gebremariam, B. (2017). Effect of land use land cover dynamics on hydrological response of watershed: case study of Tekeze Dam watershed, northern Ethiopia. International Soil and Water Conservation Research, 5(1), 1-16.

69. Wilson, C. O., \& Weng, Q. (2011). Simulating the impacts of future land use and climate changes on surface water quality in the Des 
Plaines River watershed, Chicago Metropolitan Statistical Area, Illinois. Science of the Total Environment, 409, 4387-4405.

70. Wu, T., Yu, Y., Wang, B. (2016). Water resources availability and the growth of housing prices in China. Resour. Resources, Conservation and Recycling. https://doi.org/10.1016/j.resconrec. 2016.06.022.

71. Wu, Y., Liu, S., Sohl, T. L., \& Young, C. J. (2013). Projecting the land cover change and its environmental impacts in the Cedar River Basin in the Midwestern United States. Environmental Research Letters, 8(2), 024025.

72. Yang, L., Feng, Q., Yin, Z., Wen, X., Si, J., Li, C., \& Deo, R. C. (2017). Identifying separate impacts of climate and land use/cover change on hydrological processes in upper stream of Heihe River, Northwest China. Hydrological Processes, 31(5), 1100-1112.

73. Ye, L., \& Grimm, N. B. (2013). Modelling potential impacts of climate change on water and nitrate export from a mid-sized, semiarid watershed in the US Southwest. Climate Change, 120(1-2), 419-431.

74. Yira, Y., Diekkrüger, B., Steup, G., \& Bossa, A. Y. (2016). Modeling land use change impacts on water resources in a tropical West African catchment. Journal of Hydrology, 537, 187-199.

75. Zessner, M., Schönhart, M., Parajka, J., Trautvetter, H., Mitter, H., Kirchner, M., Hepp, G., Blaschke, A. P., Strenn, B., \& Schmid, E. (2017). A novel integrated modelling framework to assess the impacts of climate and socio-economic drivers on land use and water quality. Science of the Total Environment, 579(1), 1137-1151.

76. Zhang, A., Zhang, C., Fu, G., Wang, B., Bao, Z., \& Zheng, H. (2012). Assessments of impacts of climate change and human activities on runoff with SWAT for the Huifa River Basin, Northeast China. Water Resources Management, 26(8), 21992217.

77. Zhao, A., Zhu, X., Liu, X., Panb, Y., \& Zuo, D. (2016). Impacts of land use change and climate variability on green and blue water resources in the Weihe River Basin of northwest China. Catena, 137, 318-327.

78. Zhou, F., Xu, Y., Chen, Y., Xu, C. Y., Gao, Y., \& Dua, J. (2013). Hydrological response to urbanization at different spatio-temporal scales simulated by coupling of CLUE-S and the SWAT model in the Yangtze River Delta region. Journal of Hydrology, 485, 113-125.

79. Zuo, D., Xu, Z., Yao, W., Jin, S., Xiao, P., \& Ran, D. (2016). Assessing the effects of changes in land use and climate on runoff and sediment yields from a watershed in the Loess Plateau of China. Science of the Total Environment, 544, 238-250.

80. Torabi Haghighi, A., \& Kløve, B. (2017). Design of environmental flow regimes to maintain lakes and wetlands in regions with high seasonal irrigation demand. Ecological Engineering, 100, 120-129.

81. Neupane, R. P., White, J. D., \& Alexander, S. E. (2015) Projected hydrologic changes in monsoon-dominated Himalaya Mountain basins with changing climate and deforestation. Journal of Hydrology, 525, 216-230. https://doi.org/10.1016/j.jhydrol.2015. 03.048 .

Publisher's Note Springer Nature remains neutral with regard to jurisdictional claims in published maps and institutional affiliations. 